\section{Recent scientific and technical books}

\section{Chemistry}

NONHEBEL, D.C., TEDDER, J.M., and WALTON, J.C. Radicals. (Cambridge Texts in Chemistry and Biochemistry.) Pp.xvi +200 . ISBN-0-521-22004-1. (Cambridge, London and New York: Cambridge University Press, 1979.) Hardcover £14; Paperback E5.50.

PERRIN, Douglas D. Z(complied by.) Stability Constants of Metal-Ion Complexes. Part B: Organic Ligands. (International Union of Pure and Allied Chemistry: Analytical Chemistry Division. Commission on Equilibrium Data. IUPAC Chemical Data Series-No. 22.) P
1263. ISBN-0-08-020958-0. (Oxford and New York: Pergamon Press, 1979.) £75; \$150.

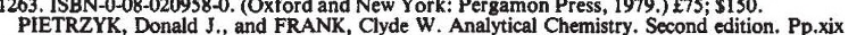
PIETRZYK, Donald J, and FRANK, Clyde W. Analytical Chemistry. Second edition. Pp.xix
$+\quad 700$. ISBN-0-12-555160-6. (New York and London: Academic Press, a Subsidiary of +700 . ISBN-0-12-555160-6. (New York and Lond
Harcourt Brace Jovanovich, Publishers, 1979.) $\$ 16.50$.

Harcourt Brace Jovanovich, Publishers, 1979.) \$16.50.
SHERWOOD, John N. (ed.) The Plastically Crystalline State: (Orientationally-Disordered Crystals). Pp.xxvi + 383. ISBN-0-471-99715-3. (Chichester and New York: Wiley-Interscience, John Wiley and Sons, 1979.) $£ 19.50$.

SUNNER, Stig, and MANSSON, Margaret (ed.) Combustion Calorimetry. (Experimental

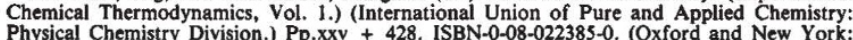
Pergamon Press, 1979.) Hard f25; Flexi $f 12.50$.

TADMOR, Zehev, and GOGOS, Costas G. Principles of Polymer Processing. (SPE Monographs.) Pp.xv + 736. ISBN-0-47.
John Wiley and Sons, 1979.) $f 24.95$

\section{Biology}

AVERY, R.A. Lizards: A Study in Thermoregulation. (The Institute of Biology's Studies in
(T) Biology, No. 109.) PP.iv + 56. ISBN-0-7131-2756-7. (London: Edward Arnold (Publishers), Ltd., 2979.) 11.80 net.

BARRASS, Robert. Modern Biology Made Simple. (Made Simple Books.)Pp.xiii +304.
ISBN-0-491-02462-2. (London: W.H. Allen, a Howard and Wyndham Company, 1979.) $£ 2.25$ net.

BERLINER, Lawrence J. (ed.) Spin Labeling II : Theory and Applications. (Molecular Biology: An International Series of Monographs and Textbooks.) Pp.xiii +357 . ISBN-0-12-
092352-1. (New York and London: Academic Press, a Subsidiary of Harcourt Bruce Ovanovich, Publishers, 1979.) \$32.

BOSCHKE, F.L. (managing editor). Biochemistry. (Topics in Current Chemistry, Fortschritte der Chemischen Forschung, Vol. 78.) Pp.

BOUTREAUX, H. Bruce. Anthropod Phylogeny, with special reference to insects. Pp.viii Sons, 1979.) f15.

BOURNE, G.H., DANIELLI, J.F. (ed.) Assisted by JEON, K.W. International Review of Cytology, Vol. 56. Pp.vii + 357. ISBN-0-12-364356-2. (New Yprk and London: Academic Press, a Subsidiary of Harcourt Brace Jovanovich, Publishers, 1979.) \$31.

BROCK, Thomas D. Biology of Micro-organisms. Third edition. Pp.xiv + 802. ISBN-0-13-

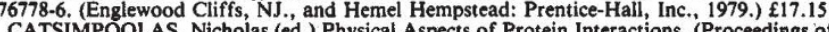
CATSIMPOOLAS, Nicholas (ed.) Physical Aspects of Protein Interactions. (Proceedings of the Symposium on Protein Interactions, American Chemical Society Meeting, Miami Beach, 0-444-00304-5. (v.3.) (New York, Ams erdam and Oxford: Elsevier/North Holland, 1978.) \$45. CHAPMAN, A.R.O. Biology of Seaweeds: Levels of Organization. Pp. xv +134 . ISBN-0-
7131-2759-7. (London: Edward Arnold (Publishers), Ltd., Baltimore, Md.: University Park Press, 1979.) £5.95 net.

CHRISTIANSEN, M. Skytte. Grasses, Sedges and Rushes in Colour. Translated by G. Hartz. Edited and adapted for the English language by C.J. Humphries and J.R. Press. Pp. 175. ISBN-0-7137-0945* . (Poole, Dorset: Blandford Press, 1979.) £3.95 net

COLE, Garry T. and SAMSON, Robert A. Patterns of Development in Conidial Fungi. Pp.xi +190 . ISBN-0-273-08407-0. (London, San Francisco and Melbourne: Pitman Publishing. Lid., 1979.) $\{29.75$.

CORLISS, John O. The Ciliated Protozoa: Characterization, Classification and Guide to the Literature. Second edition. Pp.xiv + 455. ISBN-0-08-018752-8. (Oxford and New York: ergamon Press, 1979.) $£ 20$.

DELANY, M.J., and HAPPOLD, D.C.D. Ecology of African Mammals. Pp.viii + 434 DELAN2-44176-5. (London and New York: Longman Group, Ltd., 1979.) 225.

DELANOIS, A.L. (section editor). Blostantics in Pharmacology, Vol. 3. (International

5. ISBN-0-08-

DOYLE, G.A., and MARTIN, R.D. (ed.) The Study of Prosimian Behavior. Pp.xvii + 696

Brace Jovanovich, Publishers, 1979.) $\$ 49.50$

Brace Jovanovich, Publishers, 1979.) $\$ 49.50$.
DUMONT, J., and NUNEZ, J. (ed.) Hormones and Cell Regulation, Vol. 3. (Proceedings of the Third I.N.S.E.R.M. European Symposium on Hormones and Cell Regulation, held at (v.3.) (Amsterdam, New York and Oxford: North-Holland Publishing Company, 1979.) Dif. $80 ; \$ 39$.

EBERT, James D., and OKADA, Tokindo S. (ed.) Mechanisms of Cell Change. Pp.xii +
343. 1SBN-0-471-03097-X. (New York and Chichester: John Wiley and Sons, 1979.) $£ 24.60+$ EDMONDS, Robert L. (ed.) Aerobiology: The Ecological Systems Approach. (US/IBP Synthesis Series, 10.) Pp.xiv + 386. 1SBN-0-87933-346-4. (Stroudsburg, Pennsylvania:
Dowden, Hutchinson and Ross, Inc., 2979. Distributed world wide by Academic Press, a Subsidiary of Harcourt Brace Jovanovich, Publishers, 1979.) \$2

EMIG, C.C. British and Other Phoronids: Keys and Notes for the Identification of the Species. (Synopses of the British Fauna, No. 13.) Pp. 57. ISBN-0-12-238750-3. (London and
New York: Academic Press, 1979. Published for the Linnean Society of London, and the New York: Academic Press, 1979. Published for the Linnean
Estuarine and Brackish-Water Sciences Association.) $\{2.80 ; \$ 5.75$.

Estuarine and Brackish-Water Sciences Association.) $\{2.80 ; \$ 5.75$.
FALENER, Frank, and TANNER, J.M. (ed.) Human Growth. 3 : Neurobiology and FALENER, Frank, and TANNER, J.M. (ed.) Human Growth. 3 : Neurobiology and
Nutrition. Pp.xviii + 606. ISBN-0-306-34463-7. (New York and London: Plenum Press,

FORD, E.B. Understanding Genetics. Pp.201. ISBN-0-571-10745-1. (London: Faber and Faber, Ltd., 1979.) £7.25 net.

FRANZ, Herbert. Okologie der Hochgebirge. (Phytologie: Klassische und Moderne Botanik
in Einzeldarstellungen.) Pp.495. ISBN-3-8001-3421-7. (Stuttgart: Verlag Eugen Ulner, 1979.)

DO 118. Septemlingual Dictionary of the Names of European Animals: Latin, German, English, French, Hungarian, Spanish, Russian.) Vol. 1: Pp.1171. ISBN-963.

GROBSTEIN, Clifford. A Double Image of the Double Helix: The Recombinant-DNA Debate. (A Series of Books in Biology.) Pp.xi + 177. ISBN-0-7167-1057-9. (San Francisco and Reading: W.H. Freeman and Company, 1979.) Hardcover 16.90 ; Softcover $£ 3.50$.

HEADSTROM, Richard. The Families of Flowering Plants. Pp.427. ISBN-0-498-01516-5. (South Brunswick and New York: A.S. Barnes and Company; London: Thomas Yoseloff, Ltd. 1978.) f12.50.

HERMANN, Henry R. (ed.) Social Intersectsm Vol. 1. Pp.xv + 437. ISBN-0-12-342201-9. New York and London: Academic Press, a Subsidiary of Harcourt Brace Jovanovich, Publishers, 1979.) \$36.

HODGSON, Ernest, BEND, John R., and PHILPOT, Richard M. (ed.) Reviews in Biochemical Toxicology. Pp.x + 316. ISBN-0-444-00317-7. (New York, Amsterdam, Oxford: Elsevier/North-Holland, 1979.) $\$ 32$.

HOLMQUIST, R. (ed.) Life Sciences and Space Research. Vol. 17: Proceedings of the Open Meeting of the Working Group on Space Biology of the Twenty-first Plenary Meeting of COSPAR, Innsbruck, Austria, 29 May -10 June 1978, and Symposium on Gravitation
Physiology, Innsbruck, Austria, 2 and 3 June 1978. Pp.ix + 306. ISBN-0-08-023416-X. Physiology, Innsbruck, Austria, 2 and 3 June 1978.
(Oxford and New York: Pergamon Press, 1979.) £31.25. JACKSON, David A. and STITCH, Stephen P. (ed.) The Recombinant DNA Debate.
Pp.xiv + 385. ISBN-0-13-767442-2. (Englewood Cliffs, NJ. and Hemel Hempstead: PrenticeHall, Inc., 1979.) £14.55.

KISLIUKK, Roy L., and BROWN, Gene M. (ed.) Chemistry and Biology of Pteridines. 1978.) (Developments in International Symposium, La Jolla, California, September 25-28, York, Amsterdam and Oxford: Elsevier/North-Holland, 1979.) np.
KORN, Edward D. (ed.) Methods in Membrane Biology, Vol. 10. Pp.xiv + 227. ISBN-0306-36801-3. (New York and London: Plenum Press, 1979.) \$29.50.

LAVERACK, M.S., and DANDO, J. Lecture Notes on Invertebrate Zoology Second edition. Pp.viii + 194. ISBN-0-632-00325-1. (Oxford and London: Blackwell Scientific

Publications, 1979.) E5.50. Jacques Monod. Pp. $x+246$. ISBN-0-12-460480-3. (New York and London: Academic Press, a Subsidiary of Harcourt Brace Jovanovich, Publishers, 1979.) \$17.50

MANI, M.S. Ecology and Phytogeography of High Altitude Plants of the Northwest Himalaya: Introduction to High Altitude Botany. Pp.xii + 205. ISBN-0-412-15710-1. (London:
Chapman and Hall, 1978. Distributed in USA by Halsted Press, a Division of John Wiley and Sons, Inc., New York.) £14.

MILLER, W.J. Dairy Cattle Feeding and Nutrition. (Animal Feeding and Nutrition: a Series of Monographs and Treasises.) Pp.xiv + 411. ISBN-0-12-497650-6. (New York and London: Academic Press, a Subsidiary of Harcourt Brace Jovanovich, Publishers, 1979.) \$25.

OSTER, George F., and WILSON, Edward O. Caste and Ecology in the Social Insects. and Guildford: Princeton University Press, 1978.) Cloth 112.50;. Paper 14.70 .

PEETERS, Hubert, and WRIGHT, Peter H. (eds.) Plasma Protein Pathology. (A Workshop on Plasma Proteins, Their Availability, Assay and Therap
$023766-5$. (Oxford and New York: Pergamon, 1979.) 110 .

POSPISILOVA, J., and SOLAROVA, J. (eds.) Water-in-Plants Bibliography, Vol. 3, 1977. (References No. 2480-3686/ACE-ZYA. Pp.vi + 111 . ISBN-90-6193-903-8. (The Hague, Boston, Mass. and London: Dr W. Junk Publishers, 1979.) Dutch guilders 55; U.S. \$28.50. RAPOPORT, S. (general editor.) FEBS: Federation of European Biochemical Societies. 12th Meeting, Dresden, 1978. Vol. S1: Gene Function. Pp.ix + 554. Vol. 52: Protein: Structure, Function and Industrial Applications. Pp.ix +522 . Vol. 53: Processing and Turnover of
Proteins and Organelles in the Cell. Pp.vii +183 . Vol. 54: Cyclic Nucleotides and Protein Proteins and Organelles in the Cell. Pp.vii +183 . Vol. 54: Cyclic Nucleotides and Protein
Phosphorylation in Cell Regulation. Pp.ix +310 . Vol. 55: Regulation of Secondary Product Phosphorylation in Cell Regulation. Pp.ix +310 . Vol. 55: Regulation of Secondary Product
and Plant Hormone Metabolism. Pp.viii +247 . Vol. 56: Molecular Diseases. Pp.vii +104 . and Plant Hormone Metabolism. Pp.viii + 247. Vol. 56: Molecular Diseases. Pp.vil
ISBN-0-08-0231659 set of 6 vols. (Oxford and New York: Pergamon Press, 1979.) $\mathrm{f} 100$

REESE, Ernst S., and LIGHTER, Frederick J. (ed.) Contrasts in Behavior: Adaptations in
the Aquatic and Terrestrial Environments. Pp.xi + 406. ISBN-0-471-91390-2. (New York and the Aquatic and Terrestrial Environments. Pp.xi +406 . ISBN-0-47.
Chichester: Wiley-Interscience, John Wiley and Sons, 1978.) f18.30.

Chichester: Wiley-Interscience, John Wiley and Sons, 1978.) f18.30.
RITTERSHAUSEN, Brian, and RITTERSHAUSEN, Wilma. Orchids in Colour. Pp.192. RITTERSHAUSEN, Brian, and RITTERSHAUSEN, Wilma. Orchids
ISBN-0-7137-0859-X. (Poolen Dorset: Blandford Press, 1979.) $\mathrm{f} 4.95$ net.

ROGERS, Dilwyn J. (compiled by.) A Bibliography of African Ecology: a Geographically and Topically Classified List of Books and Articles. (African Bibliographic Center. Special and London: Greenwood Press, 1979.1 f22.95.

ROODYN, Donald B. (ed.) Subcellular Biochemistry, Vol. 6. Pp.xviii + 526. ISBN-0-30640113-4. (New York and London: Plenum Press, 1979.) \$45. ROSS, Ian K. Biology of the Fungi: Their Development, Regulation, and Associations.
(McGraw-Hill Series in Organismic Biology.) Pp.xii + 499. ISBN-0-07-053870-X. (New York and London: McGraw-Hill Book Company, 1979.) np.

ROZEN, P., EIDELMAN, S., and GILAT, T. (eds.) Gastrointestinal Cancer: Advances in Diagnostic Techniques and Therapy. (Frontier of Gastrointestinal Research Vol. 5.) (Selected Papers of the International Conference, Tel Aviv, November 1977.) Pp.xiv + 226. ISBN-38055-2905-8. Basle, London and New York; S. Karger, 1979.) Sw. fr. 95; DM 114; \$57.
RUSSELL-HUNTER, W.D. A Life of Invertebrates. Pp.xvii + 650. ISBN-0-02-404620-5. (New York: Macmillan Publishing Co., Inc., London: Collier Macmillan Publishers, 1979.)

SAUNDERS, D.S. Insect Clocks. (Pergamon International Library of Science, Technology,
Engineering and Social Studies.) Pp. viii + 279. ISBN-0-08-024402-5. (Oxford and New York: Engineering and Social Studies.) Pp.viii + 279. ISBN-0-08-024402-5. (Oxford and New York: Pergamon Press, 1979.) £5.50.

SCHLESSINGER, David. (ed.) Microbiology - 1979. Pp.ix + 356. ISBN-0-914826-20-4. Washington, DC.: American Society for Microbiology, 1979.) $\$ 22$.

SEBEK, O.K., and LASKIN, A.I. (eds.) Genetics of Industrial Micro-organisms. (Proceedings of the Third International Symposium held at The University of Wisconsin, Madison,
Wisconsin, 4-9 June 1978.) pp.xii + 283. ISBN-0-914826-19-0. (Washington, D.C.: American

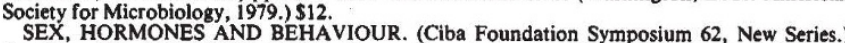
Pp.viii + 382. ISBN-90-219-4068-X. (Amsterdam, Oxford and New York: Excerpta Medica, 1979.) Dfl. 84; \$41.

SHARP; Gary D., and DIZON, Andrew E. (eds.) The Physiological Ecology of Tunas. Pp.xvi $+485+8$ plates. ISBN-0-12-639180-7. (New York and London: Academic Press, a Subsidiary of Harcourt Brace Jovanovich, Publishers, 1978.) \$29.50

STENLAKE; J.B. Foundations of Molecular Pharmacology. Vol. 1: Medicinal and Pharmaceutical Chemistry. Pp.xi + 936. ISBN-0-485-11171-3. \{36. Vol. 2: The Chemical Basis of Drug
Action. Pp. vii + 318. ISBN-0-485-11172-1. 118.50 . (London: The Athlone Press of the University of London, 1979 .

UMEZAWA, Hamao, TAKITA, Tomohisa, and SHIBA, Tetsuo (eds.) Bioactive Peptides Produced by Micro-organisms. Pp.xii + 275. ISBN-0-470-26562-0. (New York and London: $£ 29.95$

WELLER, M. Protein Phosphorylation: The Nature, Function, and Metabolism of Proteins Which Contain Covalently Bound Phosphorus. Pp. 557. ISBN-0-85086-062-8. (London: Pion Ltd., 1979.) E29.
WEVER, Ernest Glen. The Reptile Ear: Its Structure and Function. Pp.xii + 1024. ISBN-0-

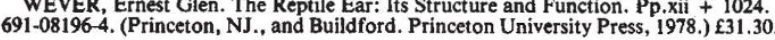

\section{Technology}

AUER, Peter. Advances in Energy Systems and Technology, Vol. 1. Pp.ix + 387. ISBN-012-014901-X. (New York and London: Academic Press, 1978.) \$32.50.

BARRON, lann, and CURNDW, Ray. The Future with Micro-Electronics: Forecasting the Ltd.; New York: Nichols Publishing Company, 1979.) £7.95

Ltd.; New York: Nichols Publishing Company, 1979.) 77.95 .
BISHOP, R.E.D., GLADWELL, G.M.L., and MICHAELSON, S. The Matrix Analysis of BISHOP, R.E.D., GLADWELL, G.M.L., and MICHAELSON, S. The Matrix Analysis of
vibration. Pp.x + 404. ISBN-0-521-04257-7. (Cambridge, London and New York: Cambridge University Press, 1979.) £30.

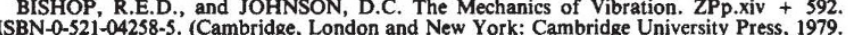
First published 1960 .) $£ 37.50$.

BURFOOT, Jack C., and TAYLOR, George W. Polar Dieletrics and Their Applications. Pp.viii + . 20 .

CARTER, Melvin W. MOGHISSI, A. Alan, and KAHNZ, Bernd. (ed.) Management of Low-Level Radioactive Waste. Vol. 1: Pp.1 - 633. Vol. 2: Pp.637 - 1214. ISBN-0-08-023907-2. Oxford and New York: Pergamon Press, 1979.) £62.50.

COHEN, Morris (ed.) Materials Science and Engineering: Its Evolution, Practice and Prospects. Contributions by M. Kranzberg, C.S. Smith, R.S. Claassen and A.G. Chynoweth. Sequoia, S.A.., 1979.) Sw. fr. $60 ; \$ 37.50$.

DREYFUS, Bertrand (ed.) The Proceedings of the Sixth International Codata Conference, May 22-25, 1978, held at The Hotel Zagarella and Sea Palace, Santa Flavia, Italy. Pp.xxiii + 433. ISBN-0-08-023371-6. (Oxford ad New York: Pergamon Pressm 1979.) £47.50.

ELECTRICAL LOAD-CURVE COVERAGE. (Proceedings of the Symposium on LoadCruve Coverage in Future Electric Power Generating Systems, organized by the Committee on 1977.) Pp.xix + 546. ISBN-0-08-022422-9. (Oxford and New York: Pergamon Press, 1979.)
(I) ⿷35. 